\title{
Strengthening and Connecting the Dots Called MSMEs in the ASEAN: With Focus on the Philippines
}

\author{
Cristina Teresa N. Lim
}

De La Salle University, Manila, Philippines

Copyright $@ 2017$ by authors, all rights reserved. Authors agree that this article remains permanently open access under the terms of the Creative Commons Attribution License 4.0 International License

\begin{abstract}
With the ASEAN's current initiative towards regional market integration, the small-and-medium scale enterprises (SMEs) in the Philippines - one of the major economic growth drivers in the country sees a potential opportunity for a considerable increased market access and a tremendous growth. For the country to become a major player in the ASEAN market and in the regional production networks, the smaller businesses must be ready to face the challenges and opportunities the economic integration brings. Thus, the paper aims to lay-out factors that are critical to the development of our local SMEs in terms of firm characteristics, investment climate, finance and current reforms which are essential to understanding the competitiveness and opportunities that the industries may seize. The regression analysis of the firms from the World Bank Enterprise Survey showed that access to credit, use of technology communication and years of experience of the managers have the greater likelihood of becoming a good market player in the ASEAN.
\end{abstract}

Keywords ASEAN, Market Integration, Regional Production Network, SMEs

\section{JEL Classification C19, G13, G14}

\section{Introduction}

The economy and its growth is one of the more pressing topics in the concluded Philippine Presidential Elections. Promised and proclaimed by all candidates, including the eventual winner and now incumbent President Rodrigo Roa Duterte, moving things upward "economically" to benefit the majority, especially the marginalized, must be seen and felt tangibly and strongly.

However, the Philippines economic growth and performance - internationally and internally remained lackluster. Oftentimes, the abundance of specks, or the many dots to which the 'Micro, Small and Medium Enterprises or MSMEs", can be likened to, have not been given its deserved attention. The entry of a new administration will very likely bring about renewed hopes and vigor, but the main expectation will be on sustainability.

The dots, the "informal business persons" have been there day in and day out doing their share for the economy. Their selling and buying which are the basics of trade; haggling and checking on supplies and demands without knowing that such acts make for robustness and management of expenses.

\section{The ASEAN Initiatives}

The MSMEs are integral workhorses, very significant drivers for job creation and economic growth not only in the Philippines but in the ASEAN region. The 10 ASEAN member countries Brunei, Cambodia, Indonesia, Laos PDR, Malaysia, Myanmar, Singapore, Thailand Vietnam and the Philippines have moved together for a higher level of cooperation, and fusing together of market integration. The ASEAN Economic Community where these member countries belong is ready for new perspectives in doing and making business. Those MSMEs that are innovative and growing rapidly are given opportunities to transform their business through positive steps that will stimulate SME growth. The move includes extensive structural reforms to enhance and encourage productivity, human capital and enterprise performance.

The ASEAN has attained this level of consciousness in the economic community. The Philippines has no recourse but to follow its neighboring and fellow ASEAN member countries in each stride.

With the ASEAN's current initiative towards regional market integration, the country's smaller businesses must be ready to face the challenges and opportunities the economic integration brings. Thus, this seeks to map out the issues that are essential to the growth of our local SMEs in terms of firm characteristics, investment climate, finance and current reforms which are essential to understanding the competitiveness and opportunities that the industries may seize. 


\section{Literature Review}

In 2006, study showed that micro, small and medium enterprises (MSMEs) dominated the economy however they only accounted two-thirds of the country's total employment and one-third total value added, and firm size distribution has also not changed significantly in the past two decades. In spite of the present programs and policies created for SMEs, access to finance has remained one of the most critical factors affecting the competitiveness of the sector where many private banks are still reluctant to lend to SMEs because of lack of credit information and low appreciation of lending to small businesses. More specific issues on SME financing include lack of acceptable collateral, slow loan processing, short repayment period, high interest rates, difficulties in loan restructuring, and lack of start-up funds.

It also raised concerns over the weak performance of SMEs despite regional measures implemented in the ASEAN Strategic Action Plan for SME Development 2010-2015 (ASAPSD), and the AS Policy Blueprint for SME Development 2004-2009 (APBSD). The study mentioned that a perception survey was conducted to evaluate the impacts of these frameworks. The study found that majority of the respondents perceived that the APBSD had limited impact on facilitating SMEs' access to information, market, human resource development and skills, finance, and technology.

Ruane (2007) looked into small-scale business enterprises in the Philippines through survey and empirical analysis to understand what determines entrepreneurial motivations and success in the Philippines. The survey is comprehensive in scope and comprised 202 questions which includes data on the general characteristics of the business enterprise and the entrepreneur and other important issues in the study of entrepreneurship such as entrepreneurial intensity, sacrifice, motivation, business plans, the business' effect on the entrepreneur's quality of life, the entrepreneur's personal beliefs and attitudes, and difficulties and problems that the entrepreneur encountered at different stages of operating the business enterprise. This analysis made use of the survey data and is based on the estimation of a regression model using Ordinary Least Squares technique.

Aldaba (2012) examined the country's policy environment for SMEs with its remaining ASEAN neighbors. The study revealed that the weak performance of SMEs were due to barriers to the country's business climate such as limited access to finance, information gaps, lack of technology and skills, and poor product quality and marketing. This situation remains as a huge challenge as it hampers the advantage of the SMEs to compete internationally and to market their products abroad.

Likewise, Mendoza (2015) analyzed the financial performance of selected micro, small, and medium enterprises using secondary data from financial statements for the past three years. Results showed the enterprises performed favorably in liquidity, activity and leverage but suffered from a low-level profitability. Using correlation analysis, the results show a significant linear relationship between liquidity and activity, liquidity and leverage, and activity and leverage. However, each of these measures has no significant relationship with profitability. Using t-tests, the results show no significant difference in the liquidity, profitability, and inventory turnover of the enterprises when grouped according to organizational form, business type, and asset size. However, a significant difference exists in receivable turnover, asset turnover, and debt ratios. The study recommends the MSMEs should revisit their strategies for improving profitability and use financial performance information in making critical decisions. Firms should connect financial performance to the larger external environment of the business so they will continue to play an important role in the growth of the economy.

The Economic Research Institute for ASEAN and East Asia (2014) recently released its ASEAN SME Policy Index in terms of the eight policy dimensions. Philippines barely average in the ASEAN in terms of policy and business environment for SMEs such as spanning institutional framework; cheaper and faster start-up and better legislation and regulation for SMEs; access to information and supporting services; access to finance; technology and technology transfer; international market expansion; promotion of entrepreneurial education; and developing stronger, more effective representation for SMEs' interests.

Hence, with the ASEAN's movement toward a single market and production base under the Asean Economic Community (AEC) by 2015, can the country's small-and-medium scale enterprises level up its competition and standards? Can the government efforts and initiatives be enough to address the barriers to their development?

\section{Methodology}

\subsection{Research Questions}

As indicated in the introduction, the research question to ask in the study - "is Philippines ready to become a major player in the ASEAN market”? The study seeks to know the factors that are primary to the growth of our local SMEs in terms of firm characteristics, investment climate, finance and current reforms.

\subsection{Analysis}

Descriptive analysis was used to map the current state of the country's MSMEs and to show factors that have been 
vital to their growth. Descriptive statistics was used to describe the basic features of the data on MSMEs in the study. They provide simple summaries about the establishments such as frequencies, percentages, ranks and averages.

Moreover, a logistic regression was done to look into the key variables that provide greater likelihood for MSMEs to perform evenly with greater profitability. In simple linear probability terms, the growth model may be described as follows:

$$
\mathrm{Y}=\beta \mathrm{X}+\varepsilon
$$

where $\mathrm{Y}$ is the vector denoting the firm's performance growth in terms of profitability, $X$ is the matrix of explanatory variables, $\mathrm{B}$ is the matrix of coefficients, and $\mathrm{E}$ is the matrix of error terms.

\subsection{Data}

Secondary data from Department of Trade and Industry and from the World Bank's Doing Business Survey was used to provide descriptive statistics of the business environment of the MSMEs. Furthermore, the 2009 World Bank's Enterprise Survey data was used to look into the possible factors that affect the performance of the MSMEs.

\section{Results and Discussion}

\section{Readiness or not? Of the Philippines' MSMEs}

Is the Philippines ready? This is a challenging question that does not seek neither to doubt nor question our capability to do so. It should be recalled that there exists the 2011-2016 Micro, Small and Medium Enterprise (MSME) Development Plan that aimed to address the key challenges and constraints which prevents the MSME sector from realizing its full potential and boosting the country's industrial growth.

The Plan laid out the overall framework in formulating action plans for a more harmonized approach to MSME development. It was developed in close consultation with national, regional, and provincial stakeholders. The implementation aspect will be carried out through linkages with stakeholder and concerted efforts of MSME Development Council in the regular monitoring, validation, and updating phase.

The value of the Philippine MSME sector cannot be understated in terms of its contribution to economic growth. The sector serves not only as supplier and subcontractor to large enterprises and exporters but also as part of the support system for logistics services. It accounted for $99.6 \%$ of total establishments in the country, contributed $61.2 \%$ to total employment and $35.7 \%$ to total value added.

The impressive numbers however, are not enough to encourage the MSME sector to be robust and propel its impact to the Philippine economy. For the past two decades, firm size distribution has not changed much as the proportion of medium sized enterprises remained small. This inertia resulted in a missing or hollowed middle of the country's industry structure. Medium enterprises remained at $0.4 \%$ while that of small enterprises was almost unchanged at $7.7 \%$. In employment and value added contribution, MSMEs registered unpretentious shares of $31.2 \%$ and 30.8\%, respectively. Micro enterprises meanwhile formed the bulk of enterprises with a share of $91.6 \%$. They accounted for a share of $4.9 \%$ of total value added and $30 \%$ of total employment.

Various challenges impede the performance of MSMEs that derail their potentials and promise in a highly competitive environment. The challenges include the high cost of doing business, lack of access to finance and market information, low productivity and competitiveness.

Further along is the presence, at times, of poor business conditions that directly affect the performance and competitiveness of all enterprises. The scenario is perceived to be more constraining for MSMEs given their relatively small size and limited resources. Moreover, MSMEs seldom qualify for bank loans due to lack of the necessary track record and collateral.

MSMEs also lack the necessary credit information that will assist banks to determine their creditworthiness. The limited capabilities of MSMEs in terms of management and financial tools confined them to remain domestic oriented rather than focusing on export markets. Another fundamental concern is the lack of access to new technology, weak technological capabilities, and failure to engage in innovation and research and development activities that hamper productivity of MSMEs.

\section{What do the Current Numbers Say?}

As of 2014, there are about 946,988 establishments in the Philippines where majority of these $(99.6 \%$ or 942,925$)$ are classified as micro, small, and medium enterprises (MSMEs) and the rest $(0.4 \%$ or 4,063$)$ are categorized as large enterprises (Table 1).

Table 1. Industry Sizes

\begin{tabular}{|c|c|c|}
\hline Size & Frequency & Percent \\
\hline MSMEs & 942,925 & 99.6 \\
\hline Micro & 851,756 & 89.9 \\
\hline Small & 87,283 & 9.2 \\
\hline Medium & 3,886 & 0.4 \\
\hline Large & 4,063 & 0.4 \\
\hline Total & 946,988 & 100.0 \\
\hline
\end{tabular}

Source: Department of Trade and Industry.

Looking at the distribution of the MSMEs by sector, most of the MSMEs in 2014 are in the wholesale and retail trade $(942,925)$ distributed as follows: repair of motor 
vehicles and motorcycle industries (437,205), accommodation and food services $(127,518)$, manufacturing $(117,642)$, other service industries $(60,668)$, information and communication $(39,107)$, financial and insurance activities $(35,691)$, human health and social work activities $(27,962)$, professional, scientific and technical activities $(18,603)$, education $(17,811)$ and administrative and support services $(16,296)$. These industries accounted for about $95.3 \%$ of the total number of MSME establishments (Table 2).

Table 2. MSMEs distribution by sector

\begin{tabular}{|c|c|c|}
\hline Sector & Frequency & Percent \\
\hline Wholesale and retail trade & 942,925 & 100.0 \\
\hline Repair of motor vehicles and motorcycle industries & 437,205 & 46.4 \\
\hline Accommodation and food services & 127,518 & 13.5 \\
\hline Manufacturing & 117,642 & 12.5 \\
\hline Other service industries & 60,668 & 6.4 \\
\hline Information and communication & 39,107 & 4.1 \\
\hline Financial and insurance activities & 35,691 & 3.8 \\
\hline Human health and social work activities & 27,962 & 3.0 \\
\hline Professional, scientific, and technical activities & 18,603 & 2.0 \\
\hline Education & 17,811 & 1.9 \\
\hline Administrative and support services & 16,296 & 1.7 \\
\hline Others & 44,422 & 4.7 \\
\hline
\end{tabular}

Source: Department of Trade and Industry.

Geographically, majority of the MSMEs were located in the National Capital Region (NCR) with $22.3 \%$ or 210,039 establishments, in Region 4-A (CALABARZON) with $15.4 \%$ or 144,909 establishments, in Region 3 (Central Luzon) with $11.2 \%$ or 105,476 , in Region 7 (Central Visayas) with $7.0 \%$ or 66,190 , and in Region 6 (Western Visayas) with $5.7 \%$ or 54,094 . These top five (5) locations accounted for about $61.6 \%$ of the total number of MSME establishments in the country (Table 3).

Table 3. MSMEs distribution by region

\begin{tabular}{|c|c|c|}
\hline Region & Frequency & Percent \\
\hline NCR & 210,039 & 22.3 \\
\hline Region 3 & 105,476 & 11.2 \\
\hline Region 4A & 144,909 & 15.4 \\
\hline Region 6 & 54,094 & 5.7 \\
\hline Region 7 & 66,190 & 7.0 \\
\hline Other regions & 362,217 & 38.4 \\
\hline Total & 942,925 & 100.0 \\
\hline
\end{tabular}

Source: Department of Trade and Industry.

Meanwhile, in terms of employment, MSMEs have generated a total of 4,891,836 jobs in 2014 and 2,897,421 for the large enterprises (Table 4). Almost $62.8 \%$ of the total jobs were generated by the MSMEs. Of these, 30.5\% or 2,372,678 jobs were generated by micro enterprises, $25.5 \%$ or $1,986,823$ by small enterprises, and $6.8 \%$ or 532,335 by medium enterprises. Majority of the jobs are generated by MSMEs in the National Capital Region(NCR) with 1,573,463 jobs (Table 5). By industry sector, MSMEs in the wholesale and retail trade, repair of motor vehicles and motorcycles generated the most number of jobs with 1,734,823 in 2014 followed by MSMEs in manufacturing, 786,268 (Table 6).

Table 4. Industry by employment Size

\begin{tabular}{|c|c|c|}
\hline Employment by Size & Frequency & Percent \\
\hline MSMEs & $4,891,836$ & 62.8 \\
\hline Micro & $2,372,678$ & 30.5 \\
\hline Small & $1,986,823$ & 25.5 \\
\hline Medium & 532,335 & 6.8 \\
\hline Large & $2,897,421$ & 37.2 \\
\hline Total & $7,789,257$ & 100.0 \\
\hline
\end{tabular}

Source: Department of Trade and Industry.

Table 5. MSMEs employment by region

\begin{tabular}{|c|c|c|}
\hline SMEs Employment by Region & Frequency & Percent \\
\hline NCR & $1,573,463$ & 32.2 \\
\hline Region 3 & 485,748 & 9.9 \\
\hline Region 4A & 703,005 & 14.4 \\
\hline Region 6 & 266,707 & 5.5 \\
\hline Other regions & $1,485,179$ & 30.4 \\
\hline Total & $4,891,836$ & 100.0 \\
\hline
\end{tabular}

Source: Department of Trade and Industry.

Table 6. MSMEs employment by sector

\begin{tabular}{|c|c|c|}
\hline SMEs Employment by Sector & Frequency & Percent \\
\hline Wholesale and retail trade & $4,891,836$ & 100.0 \\
\hline Repair of motor vehicles and motorcycle industries & $1,734,823$ & 35.5 \\
\hline Accommodation and food services & 678,275 & 13.9 \\
\hline Manufacturing & 786,268 & 16.1 \\
\hline Financial and insurance activities & 238,438 & 4.9 \\
\hline Education & 274,750 & 5.6 \\
\hline Other sectors & $1,179,282$ & 24.1 \\
\hline
\end{tabular}

Source: Department of Trade and Industry.

In terms of value-added, the MSME sector contributed $35.7 \% 1$ of the total with manufacturing contributing the largest share of $6.87 \%$ (Table 7). Wholesale and retail trade and repair contributed $6.58 \%$ followed by financial intermediation with a share of $6 \%$. Within the sector, small enterprises accounted for the largest share of $20.5 \%$. Medium enterprises followed with a share of $10.3 \%$ while micro enterprises registered a share of $4.9 \%$. In terms of exports, MSMEs account for $25 \%$ of the country's total exports revenue (Table 8). 
Table 7. Sales and Census Value-Added

\begin{tabular}{|c|c|}
\hline Sales and Census Value-Added & Percent \\
\hline MSMEs & 35.7 \\
\hline Micro & 4.9 \\
\hline Small & 20.5 \\
\hline Medium & 10.3 \\
\hline Large & 64.3 \\
\hline Total & 100.0 \\
\hline
\end{tabular}

Source: Department of Trade and Industry.

Table 8. Industry's contribution to exports

\begin{tabular}{|c|c|}
\hline Exports Contribution & Percent \\
\hline MSMEs & 25.0 \\
\hline Large & 75.0 \\
\hline Total & 100.0 \\
\hline
\end{tabular}

Source: Department of Trade and Industry.

In terms of ease of doing business rank, the Philippines have slipped to 103rd place among 189 economies, down with six notches from its previous rank of 95th in the previous report (Table 9). The fall in ranking is reflected in a drop in a number of indicators such as starting a business, dealing with construction business, registering property, getting credit, paying taxes and some others. This has also shifted the country's position in ASEAN, dropping it one place to 6th behind Singapore, Malaysia, Thailand, Brunei, and Vietnam. For the country, it takes 16 steps to start a business which is more steps than the ASEAN average, but the number of days it takes to start a business is 29 days which is faster compared to its neighbors (Table 10). Trade across border rank is 95 which are relatively much better compared to the ASEAN neighbors but with a relatively high cost to export (456USD) and import (580USD) border compliance Table 11). Getting credit rank of the country is also one of the worst in ASEAN region with a rank of 109 out of 160 economies with credit bureau coverage of only 14 (\% of adults).

Table 9. Ease of doing business ranks by subcategories, 2016

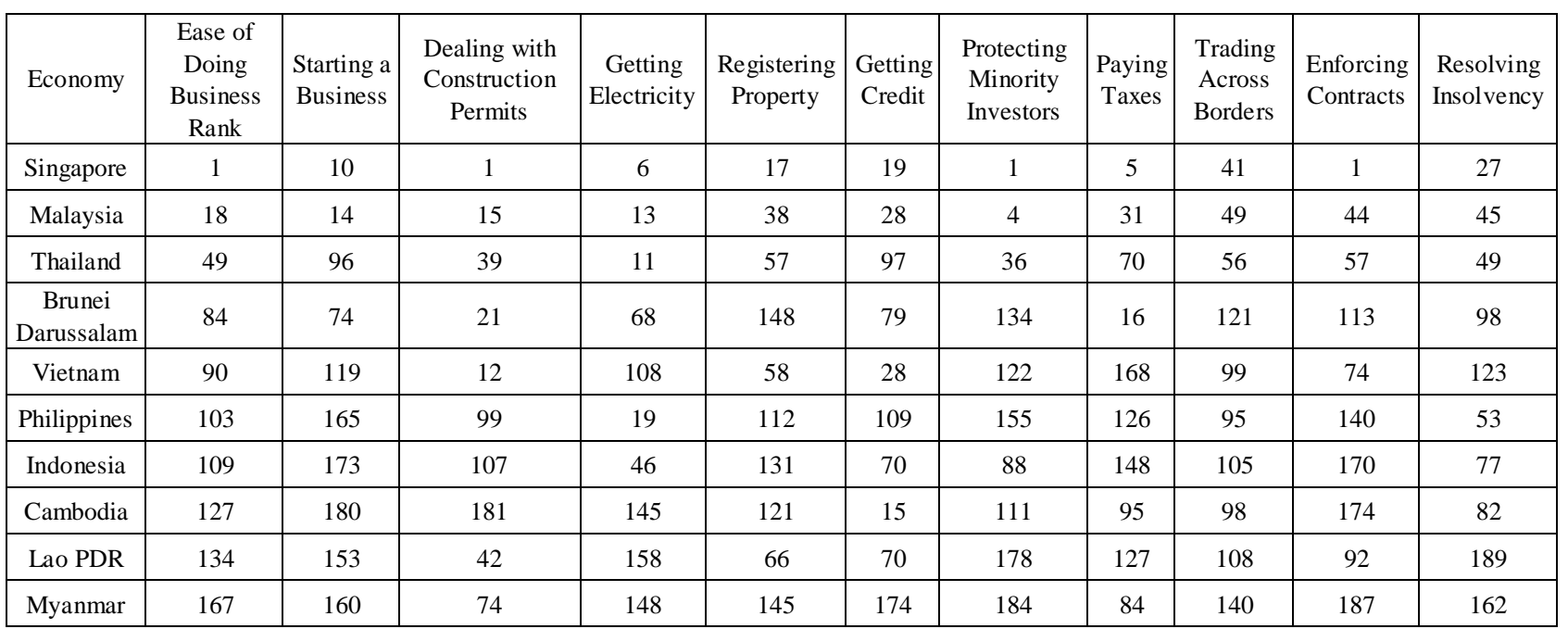

Source: World Bank, Doing Business. 
Table 10. Starting a business

\begin{tabular}{|c|c|c|c|c|c|c|c|c|}
\hline \multirow[b]{2}{*}{ Economy } & \multirow[b]{2}{*}{ Ease of Doing Business Rank } & \multirow[b]{2}{*}{ Overall DTF } & \multicolumn{6}{|c|}{ Starting a Business } \\
\hline & & & Rank & DTF & $\begin{array}{c}\text { Procedures } \\
\text { (number) }\end{array}$ & Time (days) & Cost (\% of income per capita) & Paid-in min. capital (\% of income per capita) \\
\hline Brunei Darussalam & 84 & 62.93 & 74 & 87.63 & 7 & 14 & 1.2 & 0 \\
\hline Cambodia & 127 & 55.22 & 180 & 58.1 & 7 & 87 & 78.7 & 24.1 \\
\hline Indonesia & 109 & 58.12 & 173 & 66.04 & 13 & 47.8 & 19.9 & 31 \\
\hline Lao PDR & 134 & 53.77 & 153 & 73.81 & 6 & 73 & 4.9 & 0 \\
\hline Malaysia & 18 & 79.13 & 14 & 95.34 & 3 & 4 & 6.7 & 0 \\
\hline Myanmar & 167 & 45.27 & 160 & 70.02 & 11 & 13 & 97.1 & 0 \\
\hline Philippines & 103 & 60.07 & 165 & 68.56 & 16 & 29 & 16.1 & 3.3 \\
\hline Singapore & 1 & 87.34 & 10 & 96.49 & 3 & 2.5 & 0.6 & 0 \\
\hline Thailand & 49 & 71.42 & 96 & 85.07 & 6 & 27.5 & 6.4 & 0 \\
\hline Vietnam & 90 & 62.1 & 119 & 81.25 & 10 & 20 & 4.9 & 0 \\
\hline
\end{tabular}

Source: World Bank, Doing Business.

Table 11. Trading across borders

\begin{tabular}{|c|c|c|c|c|c|c|c|c|c|c|c|c|}
\hline \multirow[b]{2}{*}{ Economy } & \multirow[b]{2}{*}{$\begin{array}{c}\text { Ease of } \\
\text { Doing } \\
\text { Business } \\
\text { Rank }\end{array}$} & \multirow[b]{2}{*}{$\begin{array}{l}\text { Overall } \\
\text { DTF }\end{array}$} & \multicolumn{10}{|c|}{ Trading Across Borders } \\
\hline & & & Rank & DTF & $\begin{array}{c}\text { Time to export: } \\
\text { Border } \\
\text { compliance } \\
\text { (hours) }\end{array}$ & \begin{tabular}{|c|} 
Cost to export: \\
Border \\
compliance \\
(USD)
\end{tabular} & $\begin{array}{c}\text { Time to export: } \\
\text { Documentary } \\
\text { compliance (hours) }\end{array}$ & $\begin{array}{l}\text { Cost to export: } \\
\text { Documentary } \\
\text { compliance (USD) }\end{array}$ & $\begin{array}{c}\text { Time to import: } \\
\text { Border compliance } \\
\text { (hours) }\end{array}$ & e $\begin{array}{c}\text { Cost to import: } \\
\text { Border } \\
\text { compliance (USD) }\end{array} \mid$ & $\begin{array}{l}\text { Time to import: } \\
\text { Documentary } \\
\text { compliance (hours) }\end{array}$ & $\begin{array}{l}\text { Cost to import: } \\
\text { Documentary } \\
\text { compliance (USD) }\end{array}$ \\
\hline $\begin{array}{c}\text { Brunei } \\
\text { Darussalam }\end{array}$ & 84 & 62.93 & 121 & 60.65 & 72 & 340 & 168 & 90 & 48 & 395 & 144 & 50 \\
\hline Cambodia & 127 & 55.22 & 98 & 67.63 & 45 & 375 & 132 & 100 & 4 & 240 & 132 & 120 \\
\hline Indonesia & 109 & 58.12 & 105 & 64.75 & 39 & 254 & 72 & 170 & 99 & 383 & 144 & 160 \\
\hline Lao PDR & 134 & 53.77 & 108 & 64.09 & 3 & 73 & 216 & 235 & 5 & 153 & 216 & 115 \\
\hline Malaysia & 18 & 79.13 & 49 & 86.74 & 20 & 321 & 10 & 45 & 24 & 321 & 10 & 60 \\
\hline Myanmar & 167 & 45.27 & 140 & 55.05 & 144 & 432 & 144 & 140 & 120 & 367 & 48 & 115 \\
\hline Philippines & 103 & 60.07 & 95 & 69.39 & 42 & 456 & 72 & 53 & 72 & 580 & 96 & 50 \\
\hline Singapore & 1 & 87.34 & 41 & 89.35 & 12 & 335 & 4 & 37 & 35 & 220 & 1 & 37 \\
\hline Thailand & 49 & 71.42 & 56 & 84.1 & 51 & 223 & 11 & 97 & 50 & 233 & 4 & 43 \\
\hline Vietnam & 90 & 62.1 & 99 & 67.15 & 57 & 309 & 83 & 139 & 64 & 268 & 106 & 183 \\
\hline
\end{tabular}

Source: World Bank, Doing Business. 
Table 12. Getting Credit

\begin{tabular}{|c|c|c|c|c|c|c|c|c|c|c|}
\hline \multirow[b]{2}{*}{ Economy } & \multirow[b]{2}{*}{$\begin{array}{l}\text { Ease of Doing } \\
\text { Business Rank }\end{array}$} & \multirow[b]{2}{*}{$\begin{array}{l}\text { Overall } \\
\text { DTF }\end{array}$} & \multicolumn{8}{|c|}{ Getting Credit } \\
\hline & & & Rank & DTF & $\begin{array}{c}\text { Strength of legal } \\
\text { rights index }(0-12)\end{array}$ & $\begin{array}{l}\text { Strength of legal rights } \\
\text { index }(0-10) \text { old } \\
\text { methodology }\end{array}$ & $\begin{array}{c}\text { Depth of credit } \\
\text { information index } \\
(0-8)\end{array}$ & $\begin{array}{c}\text { Depth of credit information index } \\
(0-6) \text { old methodology }\end{array}$ & $\begin{array}{c}\text { Credit registry } \\
\text { coverage (\% of adults) }\end{array}$ & $\begin{array}{l}\text { Credit bureau } \\
\text { coverage (\% of } \\
\text { adults) }\end{array}$ \\
\hline $\begin{array}{c}\text { Brunei } \\
\text { Darussalam }\end{array}$ & 84 & 62.93 & 79 & 50 & 4 & 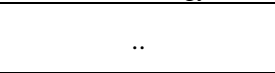 & 6 & .. & 61.2 & 0 \\
\hline Cambodia & 127 & 55.22 & 15 & 80 & 11 & .. & 5 & .. & 0 & 37 \\
\hline Indonesia & 109 & 58.12 & 70 & 55 & 5 &.. & 6 & .. & 48.5 & 0 \\
\hline Lao PDR & 134 & 53.77 & 70 & 55 & 6 &.. & 5 &.. & 5.1 & 0 \\
\hline Malaysia & 18 & 79.13 & 28 & 70 & 7 & .. & 7 & .. & 57 & 77.1 \\
\hline Myanmar & 167 & 45.27 & 174 & 10 & 2 & .. & 0 & .. & 0 & 0 \\
\hline Philippines & 103 & 60.07 & 109 & 40 & 3 & .. & 5 &.. & 0 & 14 \\
\hline Singapore & 1 & 87.34 & 19 & 75 & 8 & .. & 7 & .. & 0 & 58.6 \\
\hline Thailand & 49 & 71.42 & 97 & 45 & 3 & .. & 6 & .. & 0 & 60.2 \\
\hline Vietnam & 90 & 62.1 & 28 & 70 & 7 & .. & 7 & .. & 41.5 & 6.9 \\
\hline
\end{tabular}

Source: World Bank, Doing Business.

Table 13. Logistic Estimates

\begin{tabular}{|c|c|c|c|c|c|}
\hline Performance & Odds Ratio & Standard Error & $\mathbf{z}$ & $\mathbf{P}>\mathbf{z}$ & \\
\hline Manager's Years of Experience & 1.0380 & 0.0154 & 2.5100 & 0.01 & $* * *$ \\
\hline Squared of Manager's Experience & 0.9994 & 0.0003 & -1.8200 & 0.07 & $* *$ \\
\hline Age of the Firm & 1.0063 & 0.0229 & 0.2800 & 0.78 & $n s$ \\
\hline Squared Age of the Firm & 0.9999 & 0.0003 & -0.2500 & 0.80 & $n s$ \\
\hline Firm with ISO Certification & 1.0689 & 0.2625 & 0.2700 & 0.79 & ns \\
\hline Firm that Uses Email for Communication & 1.6646 & 0.3154 & 2.6900 & 0.01 & $* * *$ \\
\hline Firm with Access to Credit line & 1.8333 & 0.4085 & 2.7200 & 0.01 & $* * *$ \\
\hline Number of Employed Staff & 0.9986 & 0.0011 & -1.2000 & 0.23 & $n s$ \\
\hline Constant & 2.1943 & 0.7727 & 2.2300 & 0.03 & $* *$ \\
\hline
\end{tabular}

Notes: ISO = International Organization for Standardization, MSMEs = micro, small and medium sized enterprises

ns - not significant, ${ }^{*} \mathrm{p}<0.1, * *<0.05, * * * \mathrm{p}<0.01$.

Binary Variable: 1 if Net Profit is Positive, 0 Otherwise

$\mathrm{N}=1,000$ MSMEs

Source: Author's calculations

Values are in Odds Ratios 
It is noteworthy to see that several variables such as (years of experience of the manager, presence of ISO certification, access to credit line and the use of email for communication) turn out as significant with the MSMEs models (see Table 13). MSMEs that have greater likelihood of performing well in terms of net profit (total sales less total expenses) are those that have access to credit (1.8333), uses email as its technology communication (1.6646) and have hired managers with longer work experience (1.0380).

\section{Concrete Steps}

The challenges and issues that derail the growth and development of MSMEs are what the 2011-2016 MSMED Plan hope to focus on and address. In harnessing vibrancy within the sector, the Plan envisions the: i) implementation of measures to create an enabling business environment and ii) provision of government support not only to improve MSME access to finance and expand market access but also to strengthen MSME productivity and competitiveness and their linkage with large enterprises and value chain networks. Moreover, coordination and monitoring of activities among national agencies and local government units (LGUs) will also be intensified to harmonize the implementation of the Plan.

Four Outcome Portfolios have been defined namely, Business Environment (BE), Access to Finance (A2F), Access to Markets (A2M), and Productivity and Efficiency (P\&E). The outcome portfolios were defined by the participants in a consultation process with major stakeholders sometime this year. Measures will be formulated in regional and provincial action plans to deliver the expected results for each portfolio.

In implementing these measures, the Plan targets a $40 \%$ contribution of the sector to total value added and generation of 2M employment by 2016. Following are the list of steps that will tangibly manifest the outcomes of each portfolio:

\section{A. Business Environment (BE)}

- The cost of doing business (taxes, fees, etc.) is affordable to MSMEs.

- The institutional support structures for the development of start-up and existing MSMEs are in place. The policies necessary to develop the MSME sector are crafted and being fully implemented.

- Support for MSME development is results based, coordinated, harmonized, and sustained by capable stakeholders at the national and local levels.

- An entrepreneurial mindset is pervasive among MSMEs and other MSME stakeholders.

- Soft and hard infrastructures for MSME development are established.

- The information required by MSMEs is available and accessible.
- MSMEs are gender-responsive and environment-friendly.

\section{B. Access to Finance (A2F)}

- The financial products, services, and support programs that MSMEs need are sustainably available and accessible even for start-up MSMEs and those in the countryside.

- The cost of obtaining MSME loans is reasonable and affordable.

- The requirements that MSMEs need to comply with to obtain loans are reasonable and manageable.

- The processes that MSMEs need to follow and documents that must be submitted to obtain loans are simplified and streamlined.

- MSMEs are trained in financial management and are able to understand and speak the language of financial institutions, while financial institutions are trained to understand and speak the language of MSMEs.

- $\quad$ Financial products and services for MSME lending are gender-responsive and environment-friendly.

- The information needed by MSMEs to access financial resources is available and easily accessible.

- The assistance extended by stakeholders to MSMEs in accessing funds is coordinated, responsive, and effective.

\section{Access to Markets (A2M)}

- MSMEs have maintained their existing markets and penetrated new and emerging markets locally and globally.

- MSMEs are competitive locally and globally.

- Marketing support systems are established and are sustainably operating.

- MSMEs are implementing the value chain approach and are benefiting from it.

- MSMEs are using information technology and intellectual property system to develop a sustainable market share and gain competitive advantage for their products and services.

- Market information needed by MSMEs is available and freely accessible.

- MSMEs have considerable share in the sustainable development market locally and globally.

- Government support programs [(e.g. One Town, One Product (OTOP) Program)] to help MSMEs access local and global markets are coordinated and highly satisfactory.

\section{Productivity and Efficiency (P \& E)}

- Government programs and policies on productivity enhancement are coordinated, effective, and highly satisfactory. 
- The MSME workforce is highly motivated and is equipped with the appropriate skills and attitude needed by MSMEs.

- The working environment of MSMEs fosters greater productivity and efficiency among the workforce.

- MSMEs are using gender-responsive and environment-friendly technologies.

- MSMEs are compliant with international quality standards.

- MSMEs are using state of the art productivity enhancing technologies.

- Information on productivity enhancement is available and freely accessible.

The 2011-2016 MSMED Plan will take into consideration global themes and cross-cutting issues related to gender, climate change, corporate social responsibility, and migration. It will likewise support the adoption of local and regional economic development, sector development, and market system development approaches.

\section{Conclusions and Recommendations}

There are sectors where MSMEs are members, and at times such membership is mainstreamed with the major industry associations and Chambers of Commerce through PHILEXPORT and PCCI. These are strong anchors and advocates of MSMEs, networked internationally and within ASEAN. Both organizations have the capacity to undertake independent research studies on their own or with partners. They are able to tap technical expertise and funding for joint research projects. There is an institutionalized broad and nationwide mechanism i.e. the MSMED Council at various levels that combines government and MSME representatives where the former is able to solicit feedback and measure outcomes of programs for the sector.

Consultations with key players at various levels should take place at least on a monthly basis. There is ample evidence that suggestions and recommendations from the private sector have been adopted by government especially in the MSME Development Plan 2011-2016. The regularity of holding annual or biennial summit of individual MSMEs and their clusters will highlight their innovative products and articulate their issues and concerns vis-à-vis government bureaucracy.

Consistent dialogue between the MSMED Council and key legislative committees concerned with specific legislation on MSME must also be conducted. The meetings, dialogues, consultations should not stop from mere talks. There should be concrete steps in establishing a more effective system of feedback, monitoring and documentation of successful policy outcomes highlighting insights and lessons learned for the sector.

Generally, the MSMEs have been doing much better in terms of employment generation but not much on sales and census value added and contribution to exports. Hence, right policy programs that would support the development of the industry must be thoroughly crafted and existing programs implemented must be assessed as well.

Moreover, the government must improve its ease of doing business operations such as starting a business, dealing with construction business, registering property, getting credit, paying taxes and some others. Currently, the number of days it takes to start a business is 29 days but benchmarking it with best countries such as Singapore with 2.5 days only to start a business. High cost of trading across border and getting credit are major challenges to these firms.

Given the above challenges, the country's MSME can become a major player in the ASEAN market with the right support from the government and in partnership with the private sector. Improving business climate and access to credit of the firms can play a major reform to what the country's figures are showing now.

Likewise, the regression analysis of the firms from the 2009 World Bank Enterprise Survey showed that access to credit, use of technology communication and years of experience of the managers have the greater likelihood of becoming a good market player in the ASEAN.

\section{REFERENCES}

[1] ASEAN SMEs - Jakarta: Economic Research Institute for ASEAN and East Asia, 2008.

[2] John, "Barriers hinder growth of SMEs - PIDS," The Manila Times, April 2013.

[3] Mendoza and Melchor, "SMEs in the Philippines: Going beyond survival," Rappler, November 2014.

[4] ERIA SME Research Working Group, ASEAN SME Policy Index 2014 "Towards Competitive and Innovative ASEAN SMEs," ERIA Research Project Report 2012-8, June 2014.

[5] Aldaba, Rafaelita M. and Aldaba, Fernando T., "Toward Competitive and Innovative ASEAN SMEs: Philippine SME Policy Index 2012," PIDS Discussion Paper Series No. 2014-30, June 2014.

[6] Micro, Small and Medium Enterprise Development Plan 2011-2016, MSMED Council, DTI.

[7] Beyond AEC 2015: Policy recommendations for ASEAN SME Competitiveness, ASEAN, August 2014.

[8] ASEAN Strategic Action Plan for SME Development 2016-2025, Jakarta: ASEAN Secretariat, November 2015.

[9] World Trade Report for 2016: Leveling the trading field for SMEs, WTO, 2016. 